Věda a perspektivy № 2(9) 2022

ISSN 2695-1584 (Print)

ISST 2695-1592 (Online)

https://doi.org/10.52058/2695-1592-2022-2(9)-234-245

\title{
Анастасія Шинкарук
}

Викладач кафедри музикознавства та вокально-хорового мистецтва. Уманський державний педагогічний університет імені Павла Тичини.

м.Умань, Україна, https://orcid.org/0000-0003-2480-3177

\section{ОСОБЛИВОСТІ ФОРМУВАННЯ ВОКАЛЬНОЇ КУЛЬТУРИ У СТУДЕНТІВ ЗАКЛАДІВ ВИЩОЇ ОСВІТИ}

Анотація. У статті здійснені систематизація й узагальнення відомостей про особливості формування вокальної культури у студентів закладів вищої освіти. Встановлено, що для досягнення необхідного рівня вокального виконання, необхідне поліпшення вокальної культури студентів: вокалістів слід виховувати, розвиваючи вокально-хорові навички. Сучасні вокальні ансамблі часто використовують елементи театральної постановки. Голоси вихованців потрібно розбудовувати поступово й обережно. Способи навчання й прийоми, за допомогою яких педагог дає студентам навички й знання вокально-хорової освіти $\epsilon$ результатом багаторічного досвіду. Робота зі студентським вокальним ансамблем із самого початку ведеться так, щоб використовувати спів по групах (партіям). В умовах багатомісячних карантинних обмежень актуальним питанням $\epsilon$ викладання вокальних дисципліни під час дистанційної форми навчання.

Ключові слова: вокал, вокальне мистецтво, вокальна традиція, мистецька школа, вокальна школа, виконавство, професіоналізація, заклади вищої освіти.

\section{Anastasiia Shynkaruk}

Lecturer at the Department of Musicology and Vocal and Choral Arts.

Uman State Pedagogical University named after Pavel Tychyna.

Uman, Ukraine, https://orcid.org/0000-0003-2480-3177

\section{PECULIARITIES OF VOCAL CULTURE FORMATION AMONG STUDENTS OF HIGHER EDUCATION INSTITUTIONS}

Abstract. The article systematizes and summarizes information about the peculiarities of the formation of vocal culture among students of higher education institutions. It was established that in order to achieve the necessary level of vocal

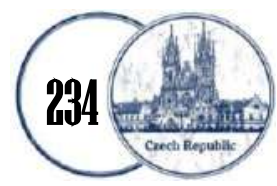


performance, the necessary improvement of the vocal culture of students: vocalists need to be raised by developing vocal and choral habits. Modern vocal ensembles often use elements of theatrical production. The voices of pupils need to be developed gradually and carefully. The teaching methods and techniques by which the teacher gives students the habits and knowledge of vocal and choral education are the result of many years of experience. From the very beginning, work with the student vocal ensemble is carried out in such a way as to use singing in groups (parts). In the face of months of quarantine restrictions, teaching vocal disciplines during distance learning is a pressing issue.

Keywords: vocal; vocal art; vocal tradition; art school; vocal school; education; professionalizing; higher education institutions.

Постановка проблеми. Актуальність вибору теми даного дослідження обгрунтована низкою сучасних тенденцій у розвитку вокальної освіти в Україні.

Вокал із стародавніх часів вважається самим доступним видом діяльності людини, пов'язаної з музичною творчістю. Однак для досягнення професійного рівня вокального виконавства, потрібна поетапна й значна робота над музичною підготовкою: вокалістів виховують, розвиваючи вокальні й ансамблеві навички. У процесі навчання співу у закладі вищої освіти особа вчиться взаємодії й взаєморозумінню в колективі, розвиває власні музичні здібності. Власне це формує вокальну культуру особистості.

Студенти виявляють цікавість до колективного співу, таким чином, одержуючи можливість набуття вокальних навичок, розширення кругозору й поповнення музичного багажу за рахунок репертуару різних епох.

Робота зі студентським вокальним колективом - це не тільки широкі горизонти розвитку, нові форми роботи й захоплюючі моменти, але й труднощі, пов'язані з об'єднанням різних форм творчості. Складності, характерні для кожного виду мистецтва окремо, ставлять нові завдання при їхньому об'єднанні. До цього додаються і вікові нюанси. Тому викладачеві необхідно запастися терпінням і деякими педагогічними прийомами, щоб утримати увагу й працездатність студентів.

Взасмопов'язаність даної дослідницької проблеми із важливими питаннями інших наук. Питання, що актуалізується у даній статті, пов'язано 3 рядом наукових дисциплін, зокрема культурологією, технікою вокального виконавства, теорію мистецтва співу та ін.

Аналіз останніх досліджень і публікацій. Вітчизняні науковці вже дослідили багато аспектів вокальної освіти, зокрема: запропоновано методику формування виконавської майстерності і вокальної культури (Д.Бабіч) [1], розглянуто пластику й постановку номера естрадного співака (Л.Красовська [2]), досліджене вокальне ансамблеве виконавство в умовах університетської освіти

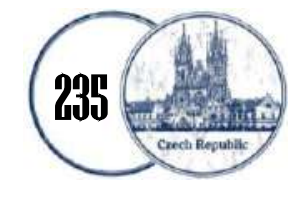


України (Т.Ланіна [4]), розроблено програму й методику роботи зі студентськими вокальними колективами (Т.Пляченко [5]), експериментально верифіковано технологію формування у студентів закладів вищої освіти навичок співу в позанавчальній діяльності (І.Шевченко [7]).

Метою даної публікації $\epsilon$ систематизація й узагальнення відомостей про особливості формування вокальної культури у студентів закладів вищої освіти.

Виклад основного матеріалу. Важливим елементом на початку заняття 3 професійної підготовки майбутніх артистів-вокалістів $\epsilon$ формування вокальної культури, яке передбачає:

- роботу над засвоєнням вокальних навичок;

- слухове настроювання вокального ансамблю;

- підготовку голосу до співу, розіграші голосових зв'язок;

- вправи для важких елементів твору, їх розучування.

В освітній роботі потрібно враховувати два важливі елементи при виспівуванні:

1) Формування єдиного тембру в унісоні.

2) Спів інтервалів - основа розвитку двохголосся тощо у залежності вокальних навичок - спів багатоголосся (акорди).

Інтонацію коректують за допомогою позиції утворення звуку. Якщо інтонація вище необхідної, їі можна виправити більш округлим і прикритим співом, а якщо низька позиція - слід ніби пересунути уперед [6].

Існує велика кількість різних вправ для додання однаковості в постановку звуку. У такому випадку дуже відома вправа для «наближення» звуку до зубів. У цьому випадку весь твір виконується на звук «д» із різними голосними: «так» - яскравість у звучанні, «ді» - довжина звуку, «ду»- прикриття звуку.

Для роботи над рухливістю голосу на початковому етапі використовуються дуже прості вправи й співаються спочатку в дужеспокійному темпі й обмеженій кількості, щоб не стомлювати гортань.

Основний принцип в цій роботі: точність інтонації, відсутність ковзань.

Все має бути виконано

Для роботи над рухливістю голосу на початковому етапі використовуються дуже прості вправи й співаються спочатку в дуже спокійному темпі й обмеженій кількості, щоб не стомлювати гортань.

Основний принцип в цій роботі: точність інтонації, відсутність ковзань.

Все має бути виконано

Для роботи над рухливістю та яскрвістю голосу на початковому етапі використовуються дуже прості вправи й співаються спочатку в дуже спокійному темпі й обмеженій кількості, щоб не стомлювати гортань.

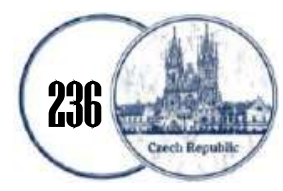


Основний принцип в цій роботі: точність інтонації, відсутність ковзань. Bсе має бути виконано чітко, інтонаційно правильно та легко, що надзвичайно важливо. Адже, якщо вокалісти все співають напружено, незв'язно, то і звук буде не гнучкий і не приємний для слухання.

Цих проблем можна уникнути тільки при ретельному контролі з боку педагога і завдяки свідомому самоконтролю, того, хто навчається. Чистої інтонації та політності звука потрібно домагатися копіткою роботою i терпінням.

Колективний вокал (ансамблі та хори) відрізняється від сольного академічного чи народного вокалу в основному цілями й завданнями вокаліста. Академічні і народні співаки працюють у рамках канону, регламентованого звучання, для них відхилятися від норми не прийнято. Завдання ансамблевих виконавців - злиття воєдино та досягнення чистого унісону, а не пошук свого власного звука, своєї оригінальної, характерної, легко упізнаваної манери співу і сценічного образу. Це властиво більше для співаків естрадного вокалу, чи джаз бендів, в яких прийнято творити щось своє, проявляти свою особливість та показувати свою унікальність. В таких колективах, зазвичай, кожен вокаліст веде свою свою вокальну лінію.

Велику роль у вокальній діяльності відіграє робота над дикцією. Якість дикції залежить від чіткості й інтенсивності проголошення приголосних. Утворення приголосних має бути швидким, тоді досягається плавність i м'якість у звучанні.

Вимова приголосних, їх яскрава чіткість, а в необхідних випадках i підкресленість - усе, що збагачує смислову суть виконання. Співак, який невикористовує усього цього, сам себе «обкрадає», одночасно «обкрадаючи» поета ікомпозитора, і що найголовніше - слухача. Навіть спів без слів (пасажі в аріях, вокалізи, чисто технічні моменти, наприклад, колоратура) має бути по можливості виправданий, повинен отримати свій смисл.Тільки в цьому випадку спів може стати справді художнім. Тут доводиться говорити про дуже прості речі, давно вже відомі, але ці «простіречі» мають глибоко принципове значення; однак, вони занадто, на жаль, часто забуваються і навіть зовсім ігноруються. 3 іншого боку, вони не такі вже прості, як здаються на перший погляд. Часто самі композитори створюють надзвичайні утруднення для співака, який прагне до художнього виконання. Завдання кожного культурного співака - здолати ці перешкоди, по можливості згладити, знівелювати, а не йти лінією найменшого опору. Прислухаючись до манери співу і характеру звучання голосу у різних співаків, можна помітити, що тільки у справжніх «майстрів співу» голосні зберігають набільшій частині діапазону голосу свої характерні звукові риси. Тільки у них « а » звучить як а, о, як о при найрізноманітніших нюансах художнього виконання. Спів у таких виконавців

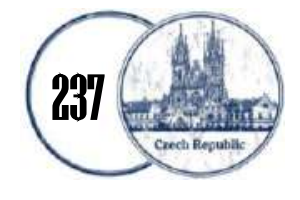


справляє враження простоти, природності й легкості. Здається, ніби виконавець не користується будь-якими штучними засобами для того, щоб голос здавався сильнішим, ширшим і насиченішим, ніж це відповідає його природному голосовому матеріалу. Якщо уважніше спостерігати за співаками то можна помітити, що ясність вимови в співі визначається не лише чіткістю артикулювання приголосних звуків, але в дуже великій мірі - ясністю i виразністю (чистотою) голосних. Засвоєні кращими співаками фонаційні навички дають їм можливість здійснити основну вимогу cantare come parlare (співати, як говорити), що практикувалось кращими представниками італійської школи співу епохи іiі розквіту, як обов'язковедля художнього співу. Ця вимога $\epsilon$ основним правилом естрадного вокалу! «Співаю, як говорю». Абсолютно інше можна спостерігати у співаків, які погано володіють голосом: голосні в їхньому співі або звучать в'яло, неясно, або ж зовсім спотворюються. Форми спотворення вокальних голосних у співаків з погано поставленими голосами дуже різноманітні. Найчастіше зустрічається «перехід» одного голосного в інший; наприклад, голосний, а звучить майже як о або, навпаки, о наближене до а, у більше нагадує о або ж є сумішшю двох голосних, щось середнє між о $і$ а. Причиною такого спотворення голосних $є$ в одних випадках перебільшене «затемнення» звуку, а в інших випадках, навпаки, надмірне його «освітлення». Нерідко при тривалому протягуванні голосних вони кілька разів змінюються, почерзі переходять одна в іншу, наприклад, з а в о і навпаки. При недостатній чіткості вимовляння голосних зазвичай неможливо розібрати в співі більшість слів навіть при задовільному артикулюванні приголосних. Інколи стає просто незрозуміло, якою мовою співає виконавець. Разом з в'ялим артикулюванням i спотворенням голосних, спостерігається ще засмічення голосних різними антихудожніми відтінками. Наприклад, так званий «піднебінний», «щічний», «гландовий», «носовий», а іноді й «горловий» відтінок звука є не чим іншим, як прямим або непрямим наслідком того або іншого дефекту у формуванні вокальних голосних. Навіть такі властивості співацького звука, як звучання «високе», «близьке», «в масці», звук «зібраний», «висунений» або,навпаки, «низьке», «далеке» звучання, звук «потиличний», «перевернений» то що залежать якщо не цілком, то вже в усякому разі переважно від міри уміння артикулювати вокальні голосні. У результаті неправильного формування голосних спів зазвичай здається неприродним, а саме звучання голосу співака, навіть за наявності у нього хорошого природного голосового матеріалу і при правильній роботі гортані і дихального апарату, у більшості випадків все ж мало задовольняє. Голосні $\epsilon$ тією формою, в яку в кінцевому результаті виливається співацький звук. Вони дозволяють яскраво звучати голосу співака. У голосних, як у фокусі, об'єднуються позитивні й негативні риси засвоєною тим або іншим співаком манери звукоутворення (постановки голосу). 
Здебільшого особлива яскравість голосу, різне піднебіння, різні вимовляння звуків, нівелювання звуком, все це стосується виконавців солістів. При співі в колективі, педагоги зазвичай контролюють та акцентують увагу на унісонному звучанні.

Студенти у ході занять опановують і розвивають ряд важливих навичок $\mathrm{i}$ якостей. Перша така навичка - уміння слухати загальне звучання. При початковій роботі зі студентом кожний вокаліст буде слухати тільки себе, намагаючись виділятися із загального колективного звучання. Співак повинен розуміти, що звучання його голосу залежить як від самого вокаліста, так і від загального звучання ансамблю. Важливо слухати весь склад колективу й зливатися з ним в єдине звучання.

Друга така навичка - уміння відчувати й дотримуватися загального ритмічного пульсу - синхронність звучання. Під синхронністю вокального звучання розуміється точний збіг у всіх співаків дрібних ритмічних деталей, що може досягатися в атмосфері єдиного розуміння й відчування темпу й ритмічного пульсу [4].

Ці дві навички є найважливішими в роботі зі студентським вокальним колективом.

Потрібно сказати, що вокальний слух має пряме відношення до сприйняття співочого голосу й до відтворення звуків. У цілому всі завдання навчання співу спрямовані на розвиток вокального слуху. У методичній літературі виділяють понад 30 прийомів розвитку вокального слуху, спрямованих на формуванні слухового сприйняття й вокально-слухових уявлень. Виділимо серед них найбільш важливі, що відносяться до навчання студентів:

слухове «вслуховування» у показ викладача 3 метою наступного аналізу;

найбільш точного; порівняльний аналіз варіантів виконання й вибір

- $\quad$ спів «по ланцюжкові»;

- $\quad$ моделювання висоти звуку рухами рук;

- $\quad$ настроювання на тональність перед початком співу;

- $\quad$ затримка звучання ансамблю на окремих нотах по руці диригента з метою вибудовування унісону;

- $\quad$ виділення важких інтонаційних оборотів у вправі;

- транспонування твору 3 метою пошуку найбільш зручної тональності;

- $\quad$ відпрацьовування ланцюгового подиху;

- $\quad$ вимова тексту активним шепотом;

- $\quad$ варіативність завдань при повторенні вправ і завчання пісенного матеріалу за рахунок способу звуковедення, яке вокалізує слова, динаміки, тембру, тональності, емоційній виразності тощо;

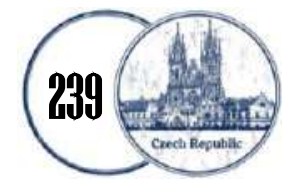


зіставлення пісенного репертуару, різного за характером, що сприяє вибудовуванню етапів уроку, а також при виборі концертної програми [3].

Доцільно викласти основні етапи розучування музичного твору зі студентами.

Найперше, що викладач повинен зробити при розучуванні твору ознайомити вокальний колектив із цим твором і проаналізувати його: зміст, будову, особливості музичної мови, загальні ідеї, засоби музичної виразності.

Далі відбувається розучування по партіях. На першому році навчання розучування партій буде відбуватися «з голосу», за допомогою фортепіано й відразу з текстом.

У більш досвідчених вокальних групах можна розучувати сольфеджіо й потім 3 текстом. Якщо студенти не знайомі з нотною грамотою - склад і текст. Якщо цей двоголосний твір - поєднання партій.

Даний етап повинен проходити 3 особливою старанністю розучування твору: окремими фразами, фрагментами, а також у повільному темпі.

Провчивши кожний фрагмент твору, можемо перейти до наступного етапу: виконання твору 3 урахуванням динамічних вказівок, ритмічних груп, мелодійних оборотів, гармонійного співзвуччя, а також значеннєвого змісту, фразування й драматургія твору.

На цьому етапі ми також включаємо роботу з мікрофонами, вибудовування звукових ефектів.

Останній етап - робота на сцені й над образом.

Потрібно відзначити, що на всіх етапах відбувається робота над текстом $\mathrm{i}$ артикуляцією.

Розглянемо основні види діяльності на заняттях зі студентським вокальним колективом.

1. Дихальна гімнастика.

2. Вправи для виспівування

3. Спів канонів - імітаційна поліфонія.

4. Розучування й робота над твором.

5. Сценічна робота [7].

Самим складним елементом у вокальній діяльності є добір репертуару, адже він повинен показати усі позитивні професійні якості виконавця.

При виборі репертуару керівник вокального колективу повинен враховувати наступні вимоги:

- твір повинний бути повноцінним за своїм ідейним змістом;

- при виборі необхідно враховувати вікові особливості вокаліста ансамблю, музичний розвиток учасників;

- твір повинен прищеплювати ансамблю співочі й музично-слухові навички, які сприяють подальшому професійному росту ансамблю й кожного вокаліста;

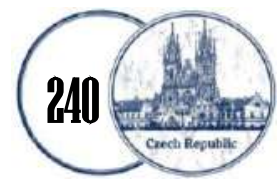


- репертуар вибирається 3 можливостями участі у концертній творчій діяльності;

- репертуар повинен бути різноманітний за жанрами і образному ладу;

- розучування твору має проходити поетапно з усім ансамблем.

Отже, голоси вихованців потрібно розбудовувати поступово й обережно. Способи навчання й прийоми, за допомогою яких педагог дає студентам навички й знання вокально-хорової освіти є результатом багаторічного досвіду. Робота зі студентським вокальним ансамблем із самого початку ведеться так, щоб використовувати спів по групах (партіям).

Підсумкова мета навчання співу - добитися того, щоби студенти співали вільно, польотним звуком, без напруження. Осмислене і якісне виконання вправ на подих при виспівуванні приводить до того, що при розучуванні твору м'язи відразу набувають правильного положення.

До завдань викладача по вокалу також входить і виправлення співочих дефектів звукоутворення: горлового звуку, носового звуку тощо. Від вірно поставлених примарних звуків і створюється подальша лінія звучання [2].

Обов'язок керівника вокального ансамблю - удосконалення методів i прийомів роботи 3 колективом, щоби вони служили не тільки цілям музичноосвітнім, але й виховним.

Однією $з$ проблем вокального ансамблю $є$ ідентичність голосів. Якщо вокалісти будуть співати різними артикуляційними рухами, то ансамблю не буде. Отже, ідентичності дикції, фонетики має приділятися величезна увага.

Спів у студентському вокальному колективі - мистецтво масове, що передбачає:

- найголовніше - колективне виконання художніх творів;

- усвідомлення студентами того, що ансамблевий спів - це гарний спів, в якому учень бере участь;

- розуміння того, що даний твір у сольному виконанні не буде звучати 3 особливим розкриттям ідейно-образного змісту;

- усвідомлення того, що колективний ансамблевий спів є головним чинником для подальшого творчого розвитку.

Вокальна культура також передбачає високий рівень володіння співаком своїми емоціями. У процесі виконання музичного твору вокаліст завжди повинен поєднувати у своєму співі раціональний і емоційний початок, думку і емоцію. Емоції, які виникають в результаті переживання в процесі співу, самі впливають на спів i, як у всякій діяльності, можуть надати як позитивну, так i негативну дію на даний процес. Саме тому, розглядаючи індивідуальні психологічні особливості викладача вокалу, які впливають на ефективність процесу створення вокального сценічного образу не можемо оминути й такий психологічний аспект як проблема сценічного хвилювання, оскільки подолання

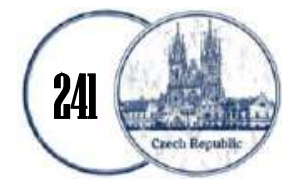


негативних наслідків даної проблеми постійно знаходиться у полі зору сучасної музично-педагогічної і музично-психологічної наукової думки [1].

Сценічне хвилювання завжди природньо супроводжує процес виступу, проте на певних стадіях свого вияву воно може стати джерелом значних розчарувань багатьох обдарованих вокалістів, що перешкоджає творчій самореалізації майбутніх фахівців. Проте необхідно пам'ятати, що естрадна обстановка не завжди і не для всіх викладачів вокалу є стресовою, тобто такою, що викликає у них сценічне хвилювання руйнівного характеру. Навпаки, результати психолого-педагогічних досліджень i практичний досвід переконують нас в тому, що відсутність сценічного хвилювання $є$ ще менш бажаною для вокаліста, ніж присутність його у надмірних гіпертрофованих формах.

Вокальна культура передбачає, що у цілому процес співу як глибинний шар людських емоцій здатний виявити найкращі фізичні й духовні якості особистості, сприяючи звільненню співака від скутості, певних комплексів, поступово допомагає опановувати секрети виконавського мистецтва. У процесі професійної підготовки вокаліста важливим є розуміння того, що психологічна свобода - це, перш за все - емоційна свобода. Голос - це багатство і варто ретельно продумати, як його зберегти, розвинути і як максимально використати його унікальний потенціал, спрямовуючи цей процес на високу місію служінню Мистецтву.

Цільовий рівень вокально-виконавської установки, на думку автора, фіксує навички, які виробляються або вже вироблені i автоматично можуть регулюватися на рівні свідомості. У звичайній ситуації установочна (автоматична) діяльність відбувається успішно - свідомий контроль за вокальним виконанням значно впливає на слухацьке сприйняття, адже будь-яке активне втручання свідомості співака i постійна його увага до цілісної структури музичного твору миттєво відбивається на звучанні голосу i, тим самим, автоматично переводить виконання з високохудожнього на навчальний рівень, сконцентрований на технічному аспекті виконання. Змістовий рівень вокально-виконавської установки - найвищий рівень психологічної регуляції. Змістовий рівень може бути як свідомим так і несвідомим, але, незалежно від цього, переконана дослідниця, саме даний рівень регуляції акумулює окремі виконавські дії і навички в єдиний комплекс безперервної й оптимальної за швидкістю сценічно-виконавською діяльністю. Цим, в кінцевому результаті, забезпечується яскравість й успішність виконання вокального твору, свідомість співака націлена не на техніку, а на «емоційну партитуру» свого виконання

У рамках вокальної культури специфічною рисою сценічно-вокального виконавства $€$ також відносна швидкоплинність вокальних творів та зіставлення контрастних творів у концертних програмах, потреба в чому диктується

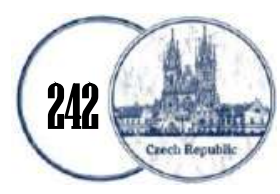


закономірностями музичного сприйняття, завданням переключати увагу слухача, змінюючи його емоційні стани. Тому надзвичайно важливою психологічною здатністю вокаліста є швидке «переключення», вміння миттєво змінювати власний психологічний стан, фонаційно-технічну готовність, засоби зовнішньо-сценічної виразності. Дієвим шляхом до такого швидкого перевтілення $\epsilon$ формування у виконавця творчої установки, логічного, ясного уявлення про загальні, концептуальні посилання автора та здатність до їх детального втілення, які забезпечуються за рахунок спроможності співака «привласнювати» характер, почуття, переживання героя твору, уміння швидко змінювати свій «персонажний стан» i психологічне самопочуття, настроюватись на той чи інший емоційний стан і діяти в руслі і логіці даного образу [5].

В умовах багатомісячних карантинних обмежень актуальним питанням $\epsilon$ викладання вокальних дисципліни під час дистанційної форми навчання. Використання елементів дистанційного навчання в процесі формування компетентності студентів-вокалістів дозволяє:

- сформувати соціально-психологічну потребу самостійного здобуття й застосування знань майбутніми вчителями вокального мистецтва в подальшій музично-педагогічній діяльності;

- організувати самостійну пізнавальну діяльність студентів-музикантів 3 використанням IT у цілому й стосовно вокального мистецтва зокрема, як основу подальшої професійної діяльності;

- реалізувати різноманітні форми зовнішнього контролю, а також самоконтролю засвоєння знань у процесі виконання теоретичних і практичних завдань, творчих проектів;

- забезпечити можливість реалізації не тільки індивідуальних, але й групових форм дистанційного навчання для спілкування з іншими студентамимузикантами;

- забезпечити можливість навчання в зручному для студента-музиканта місці, за графіком, що обумовлено особливостями процесу навчання майбутніх учителів музики (наявність додаткових репетицій, концертна й конкурсна діяльність тощо);

- створити умови для входження майбутніх учителів музики у світове освітнє й професійне середовище за рахунок удосконалювання інформаційної й професійної підготовки [2, 3].

Висновки. Отже, розглянувши проблематику даної публікації, ми прийшли до наступних висновків:

Щоби досягнути необхідного рівня вокального виконання, необхідне поліпшення вокальної культури студентів: вокалістів слід виховувати, розвиваючи вокально-хорові навички. Сучасні вокальні ансамблі часто 
Věda a perspektivy № 2(9) 2022

ISSN 2695-1584 (Print)

ISSN 2695-1592 (Online)

використовують елементи театральної постановки. Така форма роботи вводиться в практику за такими причинами:

- Сприйняття є багато у чому наочно-образним, i тому глядачам i артистам легше вникнути у зміст вокального твору, що виконується ансамблем, вбачаючи його конкретне втілення на сцені.

- Сучасні тенденції подачі інформації в Інтернеті й на телебаченні через постійну зміну картинок і зображень формують у глядачів і артистів пріоритет сприйняття інформації не через слово, а через зоровий образ. Часто виконавцям складно зрозуміти художній зміст пісні, що виконується ними у вокальному ансамблі, якщо воно не підкріплене конкретним зоровим образом. При цьому навіть виразних засобів музики може виявитися недостатньо. Усе це робить необхідним конкретизувати на сцені зміст, закладений у тексті вокального твору.

- Включення у вокальну роботу елементів театральної постановки пожвавлює репетиційний процес, дозволяє розбудовувати не тільки музичні й вокальні дані артистів-вокалістів, але й артистизм, пластику, сценічну волю.

\section{Лimepamypa:}

1. Гнидь, Б. П. (1997). Історія вокального мистецтва. Київ: НМАУ.

2. Грищенко, Ю. В. (2000). Київська вокальна школа. Украӥнське мистеитво у полікультурному просторі, Київ: ЕксОб, 119-129.

3. Грищенко, Ю. В. (2010). Розвиток професійної вокальної освіти в Україні (кінець XIX - початок XX ст.). Житомир.

4. Желан, А. (2004). Вплив видатних педагогів на розвиток музично-культурного середовища Миколаївщини кінця XIX - початку XX століть. Теоретико-методичні проблеми виховання учнів загальноосвітніх шкіл, Київ: Інститут проблем виховання АПН України, 84-87.

5. Малиніна, I. О. (2000). Школи образотворчого мистецтва України кінця XIX початок XX ст. Матеріали науково-практичної конференції молодих вчених за 2000 рік, Харків: Харківський державний педагогічний університет ім. Г.С.Сковороди, 19-20.

6. Мельник, М. Т. Стиль: поняття та специфіка прояву в моді. Retrieved from URL: http://vuzlib.com/content/view/1560/62.

7. Оленюк, Д. В. (2009). Західноєвропейська вокальна традиція та їі вплив на українську культуру оперного співу (XIX - початок XX століття). Актуальні проблеми історії, теорії та практики художньої культури, Київ: Міленіум, 271-277.

8. Попович, М. (2001). Нарис історії культури України. Київ: Артек.

9. Розенберг, Р.М. (1995). Музыкальная Одесса. Одеса: Ред.-изд. отдел обл. управления по печати.

10. Романенкова, Ю. В. (2009). Мировоззренческие универсалии периодов stilwandlung в мировом художественном процессе. Киев: Химджест.

11. Станішевський, Ю. О. (2002). Національний академічний театр опери та балету України імені Тараса Шевченка: історія і сучасність. Київ: Музична Україна

12. Шмагало, Р. Т. (2013). Мистецька освіта й мистецтво в культуротворчому процесі України XX-XXI ст. Львів: ЛНАМ; Тернопіль: Мандрівець.

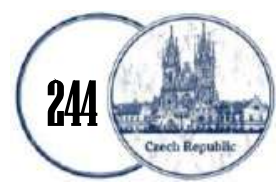




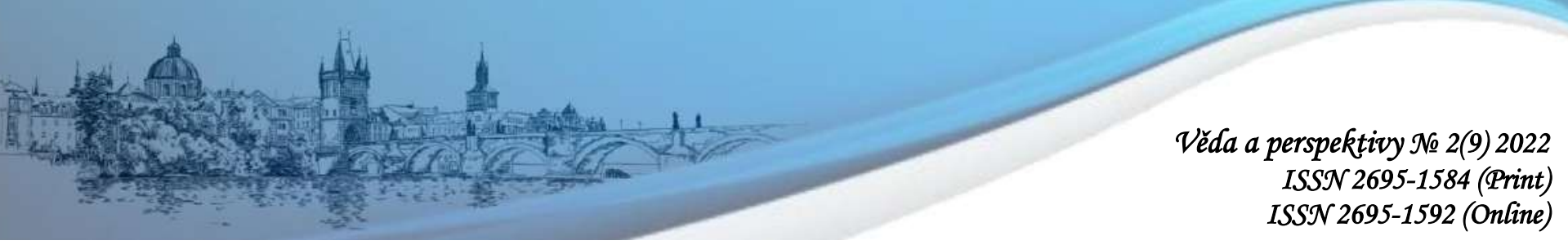

\section{References:} Ukrainian].

1. Gnid', B. P. (1997). Istorija vokal'nogo mistectva [History of vocal art]. Kiïv: NMAU [in

2. Grishhenko, Ju. V. (2000). Kiïvs'ka vokal'na shkola. Ukraïns'ke mistectvo u polikul'turnomu prostori [Kyiv Vocal School. Ukrainian art in a multicultural space]. Kiïv: EksOb [in Ukrainian].

3. Grishhenko, Ju. V. (2010). Rozvitok profesijnoï vokal'noï osviti v Ukraïni (kinec' XIX pochatok XX st.) [Development of professional vocal education in Ukraine (late XIX - early XX centuries)]. Zhitomir [in Ukrainian].

4. Zhelan, A. (2004). Vpliv vidatnih pedagogiv na rozvitok muzichno-kul'turnogo seredovishha Mikolaïvshhini kincja XIX - pochatku XX stolit' [Influence of outstanding teachers on the development of the musical and cultural environment of Mykolayiv region in the late XIX - early XX centuries]. Teoretiko-metodichni problemi vihovannja uchniv zagal'noosvitnih shkil - Theoretical and methodological problems of education of secondary school students, 84-87 [in Ukrainian].

5. Malinina, I. O. (2000). Shkoli obrazotvorchogo mistectva Ukraïni kincja XIX - pochatok XX st. [Schools of Fine Arts of Ukraine in the late XIX - early XX centuries]. Proceedings from: VI Naukovo-praktichnoï konferenciï molodih vchenih za 2000 rik «Marketynh innovatsii i innovatsii v marketynhu»- The Scientific-practical conference of young scientists in 2000. (pp. 19-20 Harkiv: Harkivs'kij derzhavnij pedagogichnij universitet im. G.S.Skovorodi [in Ukrainian].

6. Mel'nik, M. T. Stil': ponjattja ta specifika projavu v modi [Style: the concept and specifics of manifestation in fashion]. vuzlib.com Retrieved from http://vuzlib.com/content/view/1560/62 [in Ukrainian].

7. Olenjuk, D. V. (2009). Zahidno€vropejs'ka vokal'na tradicija ta iii vpliv na ukraïns'ku kul'turu opernogo spivu (XIX - pochatok XX stolittja) [Western European vocal tradition and its influence on the Ukrainian culture of opera singing (XIX - early XX century)]. Aktual'ni problemi istoriï, teoriï ta praktiki hudozhn'oï kul'turi - Actual problems of history, theory and practice of art culture, 271-277 [in Ukrainian].

8. Popovich, M. (2001). Naris istoriï kul'turi Ukraïni [Essay on the history of culture of Ukraine]. Kiïv: Artek [in Ukrainian].

9. Rozenberg, R.M. (1995). Muzykal'naja Odessa [Musical Odessa]. Odesa: Red.-izd. otdel obl. upravlenija po pechati [in Ukrainian].

10. Romanenkova, Ju. V. (2009). Mirovozzrencheskie universalii periodov stilwandlung v mirovom hudozhestvennom processe [Worldview universals of stilwandlung periods in the world art process]. Kiev: Himdzhest [in Ukrainian].

11. Stanishevs'kij, Ju. O. (2002). Nacional'nij akademichnij teatr operi ta baletu Ukraïni imeni Tarasa Shevchenka: istorija i suchasnist' [Taras Shevchenko National Academic Opera and Ballet Theater of Ukraine: History and Modernity]. Kiïv: Muzichna Ukraïna [in Ukrainian].

12. Shmagalo, R. T. (2013). Mistec'ka osvita j mistectvo v kul'turotvorchomu procesi Ukraïni XX-XXI st. [Art education and art in the cultural process of Ukraine in the XX-XXI centuries]. L'viv: LNAM; Ternopil': Mandrivec' [in Ukrainian].

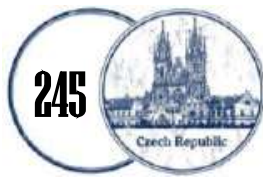

